\title{
POWERS OF THE SOUTH AFRICAN NATIONAL DEFENCE FORCE TO ENFORCE SOUTH AFRICAN LAW AT SEA
}

\section{André Smit \\ State Law Adviser (International Law)}

\begin{abstract}
Law enforcement at sea requires specialised capabilities, training and legislation due to the unique legal and physical environment within which it is conducted. The South African National Defence Force (SANDF) is increasingly deployed to enforce South African law at sea, and a constitutional democracy with entrenched human rights requires that the SANDF performs this function in a lawful and compliant manner with reference to international and domestic law. The present study sought to contribute to a greater understanding of the legal framework for law enforcement at sea by the military, and surveyed the applicable international and domestic legal prescripts. The law enforcement powers of the SANDF are pointed out in this article and discussed in the context of the applicable legal prescripts that straddle the boundaries between a number of different areas of law. Some observations are made on possible human rights concerns, cooperation with other government departments, and considerations for the military commander are pointed out before conclusions are drawn.
\end{abstract}

\section{Introduction}

The Republic of South Africa is a maritime nation with a coastline that exceeds 3900 kilometres. Its exclusive economic zone (EEZ) encompasses more than 1,5 million square kilometres, and a successful claim to a continental shelf could potentially add an additional 880000 square kilometres to the South African

Scientia Militaria, South African Journal of Military Studies, Vol 45, No. 2, 2017, pp. 36-63. doi : $10.5787 / 45-2-1209$ maritime area of interest. The South African dependence on maritime rights is accentuated by the fact that the shipping lanes around the southern tip of Africa are some of the busiest shipping lanes in the world, and maritime transport and trade is the 
lifeline of the South African energy, manufacturing, mining and retail sectors. Importantly, the contribution of commercial fishing to the economy as well as food security cannot be understated, and the commercial fishing industry is valued at more than R4,8 billion annually, and contributes hundreds of thousands of tons of fish to the diet of ordinary South Africans. Globally, it is estimated that fish provides approximately $25 \%$ of world animal protein supply, and a lack of protection, control and measures to ensure sustainability of fishing stocks could have devastating effects for coastal states such as South Africa. ${ }^{1}$

Illegal fishing is increasing in the South African EEZ. Recent incidents of South African law enforcement agencies acting against foreign vessels suspected of illegally fishing in the South African EEZ bear testimony to this fact. Role players in policing South African marine zones are the Department of Agriculture, Forestry and Fisheries (DAFF), Department of Transport, South African Maritime Safety Authority, Department of Environmental Affairs and Tourism, South African Police Service (SAPS), Department of Home Affairs, South African Revenue Service (SARS), National Sea Rescue Institute (NSRI) and Department of Defence (primarily in the form of the South African Army, Air Force and Navy). Such incidents illustrate the critical role of DAFF and the South African Navy in the initial interception of suspect vessels. ${ }^{2}$

In practical terms, it is only DAFF and the Department of Defence that maintain the resources that are required to intercept and seize vessels engaged in illegal fishing in the EEZ, or conduct maritime hot pursuit operations that extend beyond the EEZ. DAFF operates a fleet of four vessels consisting of three inshore protection vessels (IPVs) and one offshore protection vessel (OPV). ${ }^{3}$ Besides a well-

${ }^{1}$ The South African Navy has published an unclassified Maritime Doctrine for the South African Navy at www.navy.mil.za/peoplesnavy/index.htm. Chapter 2 of the Maritime Doctrine contains a compilation of facts from which the summary provided herein was drawn. It can be viewed at www.navy.mil.za/sangp100/sangp100_ch02.pdf; also see Simpson, G 'Collaboration, the Currency of SA's Ocean Expansion' (2016) Ship Year at 32-3; Beckner, J 'South African Air Border Control: The Maritime Challenge' (2011) 3 (12) Global Aviator at 32.

${ }^{2}$ The following websites provide an overview of the major incidents reported in May and June of 2016: mg.co.za/article/2016-05-19-00-sa-at-sea-over-illegal-fishing-in-its-waters; www.iol.co.za/news/crime-courts/3-more-chinese-fishing-vessels-arrested-2025436; ewn.co.za/2016/05/24/600-tons-of-squid-found-on-3-Chinese-trawlers-in-SA-waters; www.timeslive.co.za/sundaytimes/stnews/2016/05/14/Seized-Chinese-trawlerescorted-to-Cape-Town-in-illegal-fishing-rumpus; blog.samsa.org.za/2016/07/01/chinese-fishing-vessels-released-from-south-africa/.

${ }^{3}$ Unknown author on the Department of Agriculture, Forestry and Fisheries official website available at www.daff.gov.za/daffweb3/Branches/Fisheries-Management/MonitoringControl-and-Surveillance/FISHPVESSELS. 
known special forces capability within the Joint Operations Division, and maritime helicopter and fixed-wing patrol aircraft maintained by the South African Air Force, the South African Navy operates approximately nine vessels (ranging from a fleet replenishment ship and frigates to coastal mine hunters and fast attack craft amongst other) that can be utilised in a direct law enforcement role. The South African Navy also operates three submarines that are useful in the indirect support role (primarily for surveillance and evidence gathering). ${ }^{4}$

The importance of the South African EEZ is evidenced by initiatives such as Operation Phakisa that is striving to unlock the potential of the Oceans Economy for South Africa, ${ }^{5}$ and by the fact that in some circles, the South African maritime domain is referred to as South Africa's "tenth province". 6 There is a new awakening to the realities that South Africa needs to strengthen its ability to protect its marine living resources and enforce its rights over its marine resources. However, as a constitutional democracy, South Africa is also committed to the rule of law and respect for human rights, and it is at the intersection of the policing of its maritime zones and respect for human rights that the law enforcement officer finds him- or herself. A brief glance at the resources mentioned above makes it clear that the SANDF could increasingly expect to find itself pressed when called upon to assist government in fulfilling this task, and the airman or seaman will increasingly become the law enforcement officer that must execute the mission.

This article aims to contribute to the clarification and dissemination of information on the general powers of the SANDF to enforce South African law at sea. It will attempt to contextualise the nature of the task to be performed by the military, summarise applicable domestic and international legal principles, raise possible concerns from a human rights perspective, and discuss possible considerations for military planners. The article does not intend to discuss the content and scope of the powers to be exercised by the individual maritime law enforcement officer comprehensively, and its scope is specifically focussed on the enforcement of South African law in the South African maritime zones. In addition, the article does not focus on maritime piracy, as this topic has been dealt with by the

\footnotetext{
${ }^{4}$ Unknown author on the equipment of the South African Navy on the South African Navy official website available at www.navy.mil.za/equipment/index.htm.

${ }^{5}$ Unknown author on 'Operation Phakisa - Oceans Economy' on the official website of the Department of Environmental Affairs available at www.environment.gov.za/projectsprogrammes/operationphakisa/oceanseconomy.

${ }^{6}$ Unknown author on the official blog site of the South African Maritime Safety Authority available at blog.samsa.org.za/tag/south-african-oceans/.
} 
author elsewhere. $^{7}$

\section{Nature of law enforcement tasks performed by the SANDF at sea}

At a conceptual level, the tasks performed by the maritime law enforcement agencies of a coastal state are ultimately aimed at safeguarding and enforcing the interests and rights of such coastal state. The exclusive rights to exploit the resources found within the maritime domain are supported by the exercise of criminal jurisdiction of the coastal state to prevent and punish violations. These rights of a coastal state include conserving and managing the living and non-living natural resources of the waters, seabed and subsoil, and the prevention and punishment of breaches of laws protecting those rights.

Practically, the maritime law enforcement officer is concerned with ensuring compliance with laws and regulations. Examples are licence and quota compliance and enforcement, the maintenance of safety standards and safety compliance, the prevention and punishment of marine pollution, and other measures as may be necessary. The physical actions taken by maritime law enforcement officers could then include crime intelligence gathering, evidence gathering and investigation of suspected criminal activities, pursuit of suspect vessels, the seizure or arrest of vessels and other equipment, boarding operations, inspections, arrest and detention of suspects, and initiation of judicial proceedings. ${ }^{8}$

During each of these actions, the maritime law enforcement officer has to manage the risks of the violation of human rights when exercising the powers conferred by law, and when the use of force to board, search, arrest or pursue suspects is required. Moreover, the maritime law enforcement officer may be faced with situations where deadly force may have to be used to protect him- or herself, or even third parties, from the threat of severe injury or death because of the actions of suspects. In these situations, maritime law enforcement officers may have to rely on international and domestic law to interpret the powers conferred on them. It is important to ascertain whether members of the SANDF have the power to enforce South African law at sea in each scenario, especially in a constitutional democracy that respects the rule of law. Where powers are conferred, it is equally important to

${ }^{7}$ Smit, AR 'Selected Aspects of Applicable International Human Rights and Humanitarian Law in Naval Counter-piracy Operations of the East Coast of Africa' in De Wet E \& Kleffner J (eds) Convergence and Conflicts (Pretoria University Press 2014) at 193210.

${ }^{8}$ As an example, the Department of Agriculture, Forestry and Fisheries issued a media statement on 9 September 2016 that details actions taken in relation to a Taiwanese vessel, the Chin Jen Wen, and the steps taken between 7 and 9 September 2016 to intercept the vessel and escort it to a port for inspection. 
be conversant with the circumstances under which such powers may be exercised, as well as with the scope and content of each of those powers.

Although it would be preferable, and indeed the norm, for civilian law enforcement officials to take any action required in this regard, the military is frequently asked to assist. The SANDF is the lead government entity in some of these law enforcement operations, or the only governmental authority present in a situation. The tasks that members of the SANDF must perform range from merely providing a platform for other law enforcement officials executing their tasks to providing active support or to conducting the law enforcement operation itself. ${ }^{9}$

By way of example, in 2003, South Africa and Australia co-operated in a classic maritime hot pursuit operation to eventually arrest the Viarsa 1, an Uruguayan-flagged vessel in what was then regarded as the longest maritime hot pursuit operation yet. The Viarsa 1 was suspected of being engaged in illegal fishing. The pursuit commenced on 07 August 2003 when an Australian law enforcement vessel ordered the Viarsa 1 to stop while in the Australian EEZ, and the crew of the Viarsa 1 decided to flee. The pursuit lasted three weeks, covered almost 4000 nautical miles and was joined by fisheries law enforcement vessels from the United Kingdom and other vessels from South Africa. With South African Navy assistance, the Viarsa 1 was eventually arrested and returned to Australia. ${ }^{10}$

\section{Legal framework}

\section{International legal framework}

For this article, the international legal framework is acknowledged to be wider than the present discussion, and includes many more multilateral treaties than those considered below. However, in the interests of limiting the discussion to the most prominent aspects to be considered, the instruments listed were kept to the bare minimum required for the provision of an analysis of the most general principles, rights and obligations applicable.

\footnotetext{
${ }^{9}$ See the article by defenceWeb of 26 May 2016: 'Navy Plays Major Role in Impounding 600 Tons of Squid and Other Fish as Well as Foreign Trawlers', available at www.defenceweb.co.za/index.php?option=com_content\&view=article \&id=43634:nav y-plays-major-role-in-impounding-600-tons-of-squid-and-other-fish-as-well-asforeign-trawlers\&catid=108:maritime-security\&Itemid=23. Also see an article by Simpson, GP 'Bethune Ocean Warrior' (2016) Ship Year at 26-31.

${ }^{10}$ Williams, J in USAToday.com Australians nab suspected illegal fishing boat after 4,000mile chase on 30 August 2003 available at https://usatoday30.usatoday.com/weather/resources/coldscience/2003-08-30-toothfishcaught_x.htm.
} 


\section{United Nations Convention on the Law of the Sea}

The United Nations Convention on the Law of the Sea (UNCLOS) of 10 December $1982^{11}$ is regarded as a reflection of customary international law in many respects. ${ }^{12}$ It determines that the sovereignty of a coastal state extends to the territorial sea, the air space over the territorial sea as well as to its bed and subsoil. ${ }^{13}$ UNCLOS also provides that a coastal state retains "sovereign rights" for the purpose of exploring and exploiting, conserving and managing the living and non-living natural resources of the waters, seabed and subsoil within the EEZ. ${ }^{14}$

Nationals of states other than the coastal state shall comply with and respect the conservation measures and with other terms and conditions established in the laws and regulations of the coastal state when fishing in the EEZ of the coastal state. Such laws and regulations must be consistent with UNCLOS, and may relate to a list of issues such as licensing, fishing quotas and enforcement procedures. ${ }^{15}$ When providing for the competence of a coastal state to enforce its rights with regard to its EEZ, UNCLOS allows a coastal state - in the exercise of its rights to explore, exploit, conserve and manage the living resources in the EEZ - to take such measures as may be necessary to ensure compliance with the laws and regulations (including fisheriesrelated provisions) adopted by it in conformity with UNCLOS. Such measures include boarding, inspection, arrest and judicial proceedings. ${ }^{16}$ It also provides that arrested vessels and their crews shall be promptly released upon the posting of reasonable bond or other security, and that coastal state penalties for violations of fisheries laws and regulations in the EEZ may not include imprisonment in the

${ }^{11}$ Available at www.un.org/Depts/los/convention_agreements/convention_overview_convention.htm

${ }^{12}$ Shaw, MN International Law 6 ed (Cambridge 2012) at 556; Dugard, J International Law: A South African Perspective 4 ed (Juta 2011) at 368. Dugard also cites various cases before the International Court of Justice wherein the provisions of the UNCLOS have been cited as evidence of customary international law at footnote 14. Also see the Joint Statement by the United States of America and the Union of Soviet Socialist Republics of 23 September 1989 at http://www.un.org/depts/los/doalos_publications/LOSBulletins/bulletinpdf/bulE14.pdf

${ }^{13}$ Arts (1) and 2(2); the territorial sea may not extent beyond 12 nautical miles from the baselines of the coastal State in accordance with art 3 of the UNCLOS.

${ }^{14} \operatorname{Art} 56(1)(a)$.

${ }^{15} \operatorname{Art} 62(4)(a)-(k)$.

${ }^{16}$ Art 73(1); arts 72(2), (3) and (4) also contain provisions that require arrested vessels and their crews to be promptly released upon the posting of reasonable bond or other security, that coastal state penalties for violations of fisheries laws and regulations in the EEZ may not include imprisonment in the absence of agreements to the contrary, and that the coastal state shall promptly notify the flag state, through appropriate channels, of the action taken and of any penalties subsequently imposed in cases involving arrest or detention of foreign vessels. 
absence of agreements to the contrary by the states concerned, or any other form of corporal punishment. ${ }^{17}$ In instances of arrest or detention of foreign vessels, the coastal state must promptly notify the flag state of the action taken and of any penalties subsequently imposed. ${ }^{18}$

With reference to the continental shelf and the sovereign rights that a coastal state holds over its continental shelf, UNCLOS confirms that a coastal state exercises sovereign rights for the purpose of exploring and exploiting the natural resources over its continental shelf. ${ }^{19}$ These rights of a coastal state over its continental shelf are exclusive, and if the coastal state does not explore the continental shelf or exploit its natural resources, no one may undertake these activities without the express consent of the coastal state. ${ }^{20}$

It is easy to describe the rights of a coastal state within its territory, but the pursuit of completeness requires that the right of hot pursuit as described in article 111 of UNCLOS, and that is exercised partly extra-territorially, be mentioned. The right of hot pursuit allows a coastal state to pursue a foreign vessel outside the territorial sea or EEZ to enforce its laws when the competent authorities of the coastal state have good reason to believe that the ship has violated the laws and regulations of the coastal state. The exercise of the right demands that pursuit must be commenced when the foreign ship or one of its boats is within the internal waters, the archipelagic waters, the territorial sea or the contiguous zone of the pursuing state, and may only be continued outside the territorial sea or the contiguous zone if the pursuit has not been interrupted. The right of hot pursuit also applies to violations of laws and regulations of the coastal state in the EEZ or on the continental shelf. The right of hot pursuit ceases as soon as the vessel being pursued enters the territorial sea of its own state or of a third state. ${ }^{21}$ There are several other formal requirements for the competent exercise of the right of hot pursuit, such as relevant positions of vessels, signalling, uninterrupted pursuit and compensation that will not be discussed in the present context. However, it is important to remember that hot pursuit may be exercised only by warships or military aircraft, or other ships or aircraft clearly marked and identifiable as being on government service and authorised to that effect. ${ }^{22}$

\footnotetext{
${ }^{17} \operatorname{Art~73(2)}$ and (3).

${ }^{18}$ Art 73(4).

${ }^{19}$ Art 77(1).

${ }^{20}$ Art 77(2).

${ }^{21}$ Art 111(1)-(3).

${ }^{22}$ Art 111(5); also see the brief discussion that follows below regarding the use of force in law enforcement operations at sea.
} 
Rome Convention on the Suppression of Unlawful Acts against the Safety of Maritime Navigation

The Rome Convention on the Suppression of Unlawful Acts against the Safety of Maritime Navigation (SUA Convention) of 10 March $1988^{23}$ is not regarded as constituting customary international law. Other than major portions of UNCLOS, the SUA Convention is applicable only between parties to it. It provides a wider basis for the prosecution of maritime-related crime than UNCLOS. It has shed the constraints that UNCLOS retains surrounding piracy when creating a further international maritime crime in respect of the place where the crime was committed, the motives of the perpetrators, and the involvement of more than one ship. South Africa, as a party to the SUA Convention, is obliged to establish and exercise criminal jurisdiction over the crime defined through Article 3(1): ${ }^{24}$

\section{Article 3}

1 Any person commits an offence if that person unlawfully and intentionally:

(a) seizes or exercises control over a ship by force or threat thereof or any other form of intimidation; or

(b) performs an act of violence against a person on board a ship if that act is likely to endanger the safe navigation of that ship; or

(c) destroys a ship or causes damage to a ship or to its cargo which is likely to endanger the safe navigation of that ship; or

(d) places or causes to be placed on a ship, by any means whatsoever, a device or substance which is likely to destroy that ship, or cause damage to that ship or its cargo which endangers or is likely to endanger the safe navigation of that ship; or

(e) destroys or seriously damages maritime navigational facilities or seriously interferes with their operation, if any such act is likely to endanger the safe navigation of a ship; or

(f) communicates information which he [or she] knows to be false, thereby endangering the safe navigation of a ship; or

${ }^{23}$ Available at www.un.org/en/sc/ctc/docs/conventions/Conv8.pdf; it is also important to take note of the 2005 Protocol to the SUA Convention, as well as other applicable instruments such as the International Convention against the Taking of Hostages of 1979 that can be found at www.un.org/en/sc/ctc/docs/conventions/Conv5.pdf; the SUA Convention as well as the 2005 Protocol to the SUA Convention was acceded to by South Africa on 8 July 2005, and entered into force for South Africa on 6 October 2005.

${ }^{24}$ Arts 5 and 6 of the SUA Convention; De Bondt, S Prosecuting Pirates and Upholding Human Rights Law: Taking Perspective, One Earth Future Working Paper (2010) at 7; art 3(2) also criminalises the attempting commission of the offence, abetting in the commission of the offence, or threatening in the context of the offence. 
(g) injures or kills any person, in connection with the commission or the attempted commission of any of the offences set forth in subparagraphs (a) to (f).

Where UNCLOS was silent on minimum rights, the SUA Convention goes further by providing certain minimum rights to be afforded. ${ }^{25}$ South Africa incorporated this crime into domestic law, as will be indicated below, and the SANDF must be ready to act when ordered to do so with reference to the combating of this crime. The SANDF may be involved in the initial arrest and handing over of the suspect to the relevant law enforcement officials who will be responsible for further detention and trial, but the process after handover will not concern the SANDF save for the real possibility of having to testify in subsequent proceedings, or having to defend itself against possible claims relating to the violation of rights, injuries or damage to property.

\section{The use of force in maritime law enforcement}

International law provides guidelines on the principles to be followed when force is used to conduct maritime law enforcement operations, and in relation to the stopping and boarding of a vessel. The International Tribunal on the Law of the Sea (ITLOS), in the matter of the MV Saiga, confirmed:

[I]nternational law ... requires that the use of force must be avoided as far as possible and, where force is inevitable, it must not go beyond what is reasonable and necessary in the circumstances. Considerations of humanity must apply in the law of the sea, as they do in other areas of international law. ${ }^{26}$

In 2007, in an arbitration ruling between Guyana and Suriname, the MV Saiga and Nicaragua case were quoted and relied upon when it was accepted that international law allows the use of force in maritime law enforcement operations provided that such force is unavoidable, reasonable and necessary. ${ }^{27}$

Although international law permits the use of force in maritime law enforcement operations, the scope thereof must be measured on a case-by-case basis in accordance with what would be unavoidable, reasonable and necessary in the circumstances. The application of these principles is subject to interpretation, and it requires extensive training to empower a law enforcement official to make the right

\footnotetext{
${ }^{25}$ Art 10.

${ }^{26}$ See paras 153-159 in M/V Saiga (Saint Vincent and the Grenadines $v$ Guinea) (No 2) ITLOS Rep 199910120 ILR 143.

${ }^{27}$ Award of the Arbitral Tribunal Constituted Pursuant to art 287 and in accordance with Annex VII of the United Nations Convention on the Law of the Sea at paras 405, 419 and 440; award of 17 September 2007, 47 ILM (2008) 66.
} 
decisions in stressful, dangerous and demanding circumstances. The level of resistance to a law enforcement action is a very important factor to be considered, and it has a direct bearing on what is reasonable and necessary in the circumstances. The gradual escalation of the level of violence, where possible and in the absence of a clear and present danger to life or limb, commences with normal communication of intent, through a show of force and aggressive manoeuvring, to the display and eventual firing of weapons. The initial use of weapons may commence without being aimed at the offending vessel or person, and in the absence of a threat to life or limb, and will not be aimed at taking a life, but at disabling a vessel to allow the law enforcement officials to discharge their responsibilities.

The use of force in the form of mounted weapons aboard a ship is of course very different from the use of force by a boarding party carrying small arms and other non-lethal equipment. Notwithstanding, the same principles apply, and it is sometimes necessary to employ the ship-borne weapon systems to enable a boarding party to board a suspect vessel.

\section{Other international law instruments}

Of ancillary interest is the fact that the Southern African Development Community (SADC) adopted a Maritime Security Strategy, ${ }^{28}$ and the African Union (AU), an African Integrated Maritime Strategy. ${ }^{29}$ The United Nations Food and Agriculture Organisation have also seen a number of states committing to the Agreement on Port State Measures to Prevent, Deter and Eliminate Illegal, Unreported and Unregulated Fishing, and this instrument is the first ever binding international treaty that focusses specifically on illicit fishing. ${ }^{30}$ Many bilateral agreements are in existence that could also regulate cooperation between states in the field of maritime law enforcement. Of course, these may have a particular bearing if the maritime law enforcement operation is a SADC, AU or multinational operation, and these aspects may have to be considered carefully in those circumstances, but they fall beyond the scope of the present discussion.

\section{Domestic legal framework}

Constitution of the Republic of South Africa, 1996

Section 200(2) of the Constitution of the Republic of South Africa, 1996, provides that the "primary object of the defence force is to defend and protect the

\footnotetext{
${ }^{28}$ Coelho, JPB African Approaches to Maritime Security: Southern Africa (Friedrich-EbertStiftung Mozambique 2013) at 13, available at http://library.fes.de/pdffiles/bueros/mosambik/10671.pdf.

${ }^{29}$ Available at https://au.int/en/documents/30928/2050-aim-strategy.

${ }^{30}$ Available at http://www.fao.org/3/a-i1644t.pdf; It was adopted in 2009, and entered into force on 5 June 2016.
} 
Republic, its territorial integrity and its people in accordance with the Constitution and the principles of international law regulating the use of force". While the defence and protection of the Republic and its territorial integrity clearly includes defending and protecting the territorial sea, the sovereign rights conferred by international law beyond the territorial sea could arguably be included in defending and protecting the Republic as well. Notwithstanding the primary object of the SANDF, section 201(2) of the Constitution, amongst other aspects, provides that only the president, as head of the national executive, may authorise the employment of the SANDF in cooperation with the SAPS, in defence of the Republic of South Africa, or in fulfilment of an international obligation.

The implication of the constitutional provisions for law enforcement at sea is that the SANDF may be employed operationally to support SAPS in maritime law enforcement operations if the SAPS were to be engaged in such operations. Another implication is that the SANDF could be employed to support another state in maritime law enforcement operations because of an international obligation, and such actions may also involve the application of the laws of a foreign state. However, the detail regarding support to another state was excluded from the scope of this article.

\section{Maritime Zones Act, 1994 (Act No. 15 of 1994)}

The Maritime Zones Act, 1994 (Act No. 15 of 1994) is an important link that confirms the existence of, and declares South African jurisdiction over its various maritime zones. It establishes South Africa's internal waters, territorial sea, contiguous zone, maritime cultural zone, EEZ and continental shelf, and provides for application of the Maritime Zones Act, 1994, to installations and to Prince Edward and Marion Islands. ${ }^{31}$ It contains the definitions of the different maritime zones and the coordinates of South Africa's straight baselines. In the absence of a specific provision in the Constitution, which incorporates South Africa's internal and territorial waters into South African territory, the Maritime Zones Act, 1994, fills a crucial gap in clarifying the legal status of these zones in domestic law. ${ }^{32}$

The Maritime Zones Act, 1994, provides that "any law in force in the Republic, including the common law, shall also apply" in its internal and territorial waters "and the airspace above its internal waters". ${ }^{33}$ In determining the South African jurisdiction in the contiguous, maritime cultural and exclusive economic zones respectively, the Maritime Zones Act, 1994, declares that the Republic shall

\footnotetext{
${ }^{31}$ S $3-9$ and 14.

${ }^{32}$ Vrancken, P 'The Marine Component of the South African Territory' (2010) 127 South African Law Journal at 207-23.

${ }^{33} \mathrm{~S} 3(2)$ and 4(2).
} 
have the right to exercise all the powers which may be considered necessary to prevent contravention of any fiscal law or any customs, emigration, immigration or sanitary law, in respect of objects of an archaeological or historical nature found in the maritime cultural zone. The Republic has the same rights and powers as it has in respect of its territorial waters, and the Republic shall have, in respect of all natural resources in the exclusive economic zone, the same rights and powers as it has in respect of its territorial waters. ${ }^{34}$

Defence Act, 2002 (Act No. 42 of 2002)

Chapter 3 of the Defence Act, 2002 (Act No. 42 of 2002) provides for the employment and use of the SANDF. Section 18 of the Act provides that, in addition to the employment of the SANDF by the president as contemplated in section 201(2) of the Constitution, the president or the Minister of Defence and Military Veterans may authorise the employment of the SANDF for service inside the Republic of South Africa, or in international waters, in order to:

- preserve life, health or property in emergency or humanitarian relief operations;

- $\quad$ ensure the provision of essential services;

- $\quad$ support any department of state, including support for purposes of socioeconomic upliftment; and

- $\quad$ effect national border control.

Section 19 is concerned with the employment of the SANDF in co-operation with SAPS and provides that the SANDF may be employed in co-operation with SAPS in terms of section 201(2)(a) of the Constitution in the prevention and combating of crime and maintenance and preservation of law and order within the Republic of South Africa. Section 20 of the Defence Act, 2002, determines the powers of members of the SANDF while being employed for a service contemplated in section 201(2) of the Constitution, and under sections 18 and 19 of the Defence Act, 2002. Although sections 18 and 19 are not framed to have a direct maritime application, it is possible that operations aimed at the preservation of life, support to other government departments, or national border control may be conducted in the maritime domain, but the use of the words "within the Republic" cannot be interpreted to mean beyond the territorial sea.

In Chapter 4 of the Defence Act, 2002, entitled "Law Enforcement Powers of the Defence Force at Sea", it is explicitly foreseen that the SANDF will be engaged in law enforcement at sea. Of importance are sections 21 to 29. Section 21 provides specific definitions for the purposes of Chapter 4. A 'military aircraft' is

\footnotetext{
${ }^{34} \mathrm{~S} 5(2), 6(2)$ and 7(2).
} 
defined as -

[A]n aircraft of the armed forces of a State having the military marks of that State, commanded by a member of the armed forces and the crew of which is subject to regular armed forces discipline' while 'warship' is defined as 'a ship belonging to the armed forces of a State bearing the external marks distinguishing such ships of its nationality, under the command of an officer duly commissioned by the government of that State and whose name appears in the appropriate service list or its equivalent, and the crew of which is under regular armed forces discipline. ${ }^{35}$

Section 22 deals with criminal and civil law enforcement, and is quoted in full below:

\section{Criminal and civil law enforcement by Defence Force}

(1) If requested by a competent Minister, the Chief of the Defence Force, with the concurrence of the Minister of Defence, may authorise the use of any military aircraft of the Defence Force or any warship of the Defence Force or any member of the Defence Force for the purpose of enforcing any provision of South African law at sea.

(2) An officer on board an aircraft or a warship contemplated in subsection (1) may enforce South African law in-

(a) the internal waters of the Republic;

(b) the territorial waters of the Republic, but any measures taken must be carried out in accordance with paragraphs 3, 4 and 5 of article 27, and paragraphs 2 and 3 of article 28, of UNCLOS; and

(c) subject to subsection (3), outside the territorial waters of the Republic.

(3) No enforcement outside the territorial waters of the Republic may take place-

(a) in the territorial waters of a foreign state, unless it takes place on board a South African ship or in pursuance of an agreement on co-operation in law enforcement with that state; and

(b) against foreign ships or those on board them, except in circumstances permitted by international law.

(4) An officer of the Defence Force acting in accordance with subsection (2)-

(a) who exercises any power referred to in this section inside or outside the Republic, must be regarded as being a peace officer as defined in section 1 of the Criminal Procedure Act, 1977 (Act 51 of 1977), and

${ }^{35} \mathrm{~S} 21$. 
may exercise such power in the same manner as a peace officer exercising such powers within the Republic;

(b) may exercise all other powers referred to in this Chapter; and

(c) may exercise all or any of the powers conferred on any enforcement authority in terms of the relevant legislation, the provisions of which are being enforced by the said officer.

This section does not affect powers contemplated in sections 25, 26, 27 and 28 , or any other matters which are within the original and exclusive jurisdiction of the Defence Force. ${ }^{36}$

Sections 23 to 27 provide guidance on the tactical considerations of law enforcement at sea with reference to the powers conferred on officials enforcing South African law at sea. Importantly, these sections indicate interests to be considered; proscribe the crime of maritime piracy; provide for the seizure of pirate ships or aircraft; and affirm the right of visit on high seas by warships and of hot pursuit of ships in accordance with UNCLOS. Section 28 places an obligation on SANDF warships and (military) aircraft to render assistance at sea, while section 29 provides for the cooperation with foreign states in law enforcement at sea.

Marine Traffic Act, 1981 (Act No. 2 of 1981)

The Marine Traffic Act, 1981 (Act No. 12 of 1981) regulates marine traffic in the Republic of South Africa, and provides for matters connected with it. With reference to powers of the South African Maritime Safety Authority (SAMSA) relating to ships on non-innocent passage through the territorial sea of the Republic of South Africa, section 9 provides for certain powers of SAMSA to be exercised when a ship is deemed to be not innocent or is believed by SAMSA to be not innocent in its passage. Section $9(1)(d)$ to $(f)$ provides that SAMSA may require the master of such a ship to produce all papers or documents relative to the ship and its cargo for inspection and copying, to allow the ship to be boarded and the ship, its cargo and equipment to be inspected, and to deliver specified persons for arrest to be dealt with according to the law.

In section 9, the person who is empowered to enforce these provisions is referred to as an 'authorized person', and this term is defined in section 1 of the Marine Traffic Act, 1981, to include any officer of the South African Navy, and any member of the SANDF above the rank of sergeant employed on police duties in terms of section 3(2)(b) of the Defence Act, 1957 (Act No. 44 of 1957), as well as any person accompanying such persons and acting under their instructions. Section 3(2)(b) of the Defence Act, 1957 (Act No. 44 of 1957) was repealed by the Defence

${ }^{36} \mathrm{~S} 23$ of the Defence Act, 2002. 
Act, 2002, in 2003, but for ease of reference, the Defence Act, 1957, provided that the SANDF, any portion thereof, or any member may be used, in the Republic of South Africa, and for achieving the objects of the service in question, on those police functions mentioned in section 5 of the Police Act, 1958 (Act No. 7 of 1958), as may be prescribed. ${ }^{37}$ However, these powers would only be conferred while they were employed by the president for the purposes specified in the repealed section $3(2)(a)$ of the Defence Act, 1957.

Although the powers conferred in the Marine Traffic Act, 1981, are relatively clear in relation to an officer of the South African Navy, the powers of the other ranks mentioned are diluted by the fact that the defence- and police-related legislation mentioned therein has been repealed. The Defence Act, 2002, fortunately determines that a reference in any law to a provision of the Defence Act, 1957, must be construed as a reference to the corresponding provision of the Defence Act, 2002. ${ }^{38}$

Marine Living Resources Act, 1998 (Act No. 18 of 1998)

Section 9 of the Marine Living Resources Act, 1998 (Act No. 18 of 1998) provides for the designation of posts or ranks in any organ of state as fishery control officers. Section 51 spells out the general powers of a fishery control officer, while section 52 details the powers of fishery control officers beyond South African waters. Sections 53 and 54 create legal grounds for the seizure of vessels and aircraft.

Other than in the instance of the Marine Traffic Act, 1981, members of the SANDF are not directly referred to, although it is possible for them to be designated as fisheries control officers by the relevant minister. However, a member of the SANDF may be able to rely on section 22(4)(c) of the Defence Act, 2002, to exercise the powers of a fishery control officer if a lawful employment of the SANDF for this purpose is in place.

Criminal Procedure Act, 1977 (Act No. 51 of 1977)

The Criminal Procedure Act, 1977 (Act No. 51 of 1977) is frequently referred to in other legislation when the powers of law enforcement officers are described in the context of maritime law enforcement operations. An example thereof is section 22(4)(a) of the Defence Act, 2002, mentioned supra. It is also of

\footnotetext{
${ }^{37}$ Note that the Defence Act, 1957 was almost totally repealed by the Defence Act, 2002, which came into operation on 23 May 2003. Also note that the Police Act, 1958 (Act 7 of 1958) has also been repealed by the South African Police Service Rationalisation, 1995 (Proclamation R.5 of 1995). For the current legislation dealing with the South African Police Service, reference must be made to the South African Police Service Act, 1995 (Act 68 of 1995).

${ }^{38} \mathrm{~S} 106(5)$ of the Defence Act, 2002.
} 
great utility in that the general provisions of the Criminal Procedure Act, 1977, are tried and tested, and are mostly of general application. The primary example would be section 49 of the Criminal Procedure Act, 1977, which sets out the powers of an authorised person to arrest a suspect. Such suspect could be a common criminal in the city, or a tough maritime pirate who is prepared to fight to the death to escape.

The provisions of the Criminal Procedure Act, 1977, which are of greatest importance in the present context are to be found in Chapters 2 and 5 that deal with search warrants, entering of premises, seizure, forfeiture and disposal of property connected with offences, and with arrest respectively. Although the Criminal Procedure Act, 1977, refers to a "peace officer", a "police officer" or other officials, it is the fact that members of the SANDF are deemed to be "peace officers" in accordance with section 22(4) of the Defence Act, 2002, when enforcing South African law at sea that imports the Criminal Procedure Act, 1977, into the operational environment of the SANDF. Specifically, the fact that such powers are conferred on a soldier of the SANDF when properly authorised to conduct maritime law enforcement operations, bestows great importance on the Criminal Procedure Act, 1977, for the military commander.

Protection of Constitutional Democracy against Terrorist and Related Activities Act, 2004 (Act No. 33 of 2004)

The Protection of Constitutional Democracy against Terrorist and Related Activities Act, 2004 (Act No. 33 of 2004) (POCDATARA), firstly aims to provide for measures to prevent and combat terrorist and related activities. Amongst other objectives and international instruments, it also gives effect to international instruments dealing with terrorist and related activities such as the SUA Convention. Marine terrorism is a phenomenon that has gained much publicity in the past, and although it may involve the deployment of military or paramilitary forces to combat it, such counter-terrorist operations remain law enforcement operations. Examples are the hijacking of the Santa Maria in 1961, and the Achille Lauro in 1985, and as these actions could not be defined as maritime piracy, another international maritime crime was required to prevent and punish actions certain states wanted to regard as crimes nevertheless. ${ }^{39}$

Section 1 of POCDATARA provides that a member of the SANDF employed in co-operation with SAPS in terms of section 201(2)(a) of the Constitution in the prevention and combating of crime and maintenance and preservation of law and order within the Republic, as contemplated in section 19(1)

\footnotetext{
${ }^{39}$ For information on the hijacking of the Santa Maria and the Achille Lauro, see the respective sites of www.maritimeprofessional.com/blogs/post/hijacking-of-the-ss-santa-maria13422 and https://global.britannica.com/event/Achille-Lauro-hijacking.
} 
of the Defence Act, 2002, would also qualify as a police official with reference to section 24 of the POCDATARA. Section 24 of the POCDATARA specifically deals with cordoning off and stopping and searching of vehicles and persons. It determines that, if a warrant is issued by a judge for the purposes provided therein, any 'police official' who identifies him- or herself as such, may take the actions specified in the warrant. ${ }^{40}$ The 'police official' may then seize any article or thing contemplated in section 24(2), while Chapter 2 of the Criminal Procedure Act, 1977, is made applicable with the necessary changes required by the context in respect of any such article or thing. ${ }^{41}$ Section 24(4) of POCDATARA furthermore makes section 29 of the Criminal Procedure Act, 1977, applicable in respect of the powers conferred upon police officials through section 24 of POCDATARA. ${ }^{42}$

Section 10 of POCDATARA provides for offences related to hijacking a ship or endangering the safety of maritime navigation. Although the other offences created in POCDATARA may also be committed incidentally in the maritime environment, it is only section 10 that is specifically related to the maritime domain, and this incorporates the actions contemplated in the SUA Convention as crimes under South African law. The offences relate to the hijacking of a ship or endangering the safety of maritime navigation, and may even stretch wide enough to incorporate actions that would otherwise be regarded as maritime piracy.

\section{Human rights and maritime law enforcement operations}

There are a few factors that make law enforcement in the maritime domain unique. The first is the fact that travelling by sea in a medium or large naval vessel is comparatively slow and expensive. On land, a suspect arrested $300 \mathrm{~km}$ from the nearest police station in a scarcely populated area could still be transported to the nearest police station in a vehicle in a matter of hours. A suspect arrested $161 \mathrm{~nm}$ from the nearest landfall by the crew of a medium or large naval vessel cannot be transported cheaply or quickly to land, and the nearest port may be even further away. The cost of travelling to a port for the sole purpose of transferring a suspect, linked to the negative implications of an unplanned interruption of the mission of the naval vessel, and the time involved (and lost) make such action prohibitive.

This is not a unique situation for the SANDF. All navies involved in

\footnotetext{
${ }^{40} \mathrm{~S} 24(1)$ and (2).

${ }^{41}$ Chapter 2 deals with search warrants, entering of premises, seizure, forfeiture and disposal of property connected with offences.

${ }^{42}$ S 29 deals with the requirement that searches are to be conducted in decent and orderly manner.
} 
maritime law enforcement are faced with the same dilemma. The European Court of Human Rights (ECtHR) is an example of where, in 1999, the Rigopoulus matter provided some additional guidance on how human rights law could be applied in this unique maritime context. ${ }^{43}$ The salient facts were that Spain arrested suspects on a Panamanian flagged vessel suspected of being involved in illegal drug trade. Panama provided consent to Spain for this purpose. The suspects relied upon their right, under European Human Rights standards, to be brought promptly before a court by alleging that their rights were violated by only appearing before a Spanish court after 16 days of detention. Considering that the naval vessels concerned had to travel approximately $5500 \mathrm{~km}(2970 \mathrm{~nm})$ from the point of arrest to the point of transfer of the suspects, the court found no violation of Article 5(3) of the European Charter of Human Rights (ECHR) that codifies the right to be brought promptly before a court.

The position taken by the ECtHR in the Rigopoulus matter was confirmed in the Medvedyev matter of 2010 that was also heard by the ECtHR. ${ }^{44}$ In the Medvedyev matter, a French naval vessel intercepted a Cambodian vessel suspected of being engaged in illegal drug trading. The interception was conducted with the authorisation of Cambodia, and the suspects who were arrested had to endure 13 days detention while the vessel carrying them traversed some $5500 \mathrm{~km}(2970 \mathrm{~nm})$ of ocean to transfer the suspects. Again, the complainants alleged a violation of Article 5(3) of the ECHR by France. Again, the ECtHR ruled that there was no violation of Article 5(3) in the circumstances. It must be noted that the ECtHR held that the period between arrest and arraignment seemed incompatible with the requirement of promptness in the Rigopoulus and Medvedyev matters, but it also held that the exceptional circumstances present justified the prolonged detention. As it was accepted to have been materially impossible to bring the suspects before the court any earlier, the court made an allowance for the unique environment with which law enforcement in the maritime environment is faced. Of further interest on the interfaces of human rights with law enforcement in the maritime domain, Article 5(1) of the ECHR provides that no one may be deprived of liberty except in certain instances, which include maritime piracy, or provisions in other treaties for such depravation of liberty. The international human rights concerns in the specific context of maritime piracy have been discussed by the same author elsewhere, and are not repeated herein due to its narrower focus. ${ }^{45}$

\footnotetext{
${ }^{43}$ Rigopoulos v. Spain ECHR (21 January 1999) Application No 37388/97.

${ }^{44}$ Medvedyev v. France ECHR (29 March 2010) Application No 3394/03.

${ }^{45}$ Smit op cit 193-210.
} 
From a domestic law perspective, most of the rights contained in the Bill of Rights of the Constitution are not only applicable to nationals (referred to as "citizens" in the Constitution ${ }^{46}$ ) but to "everyone". ${ }^{47}$ As the persons arrested by the SANDF in law enforcement operations at sea may be foreign nationals, this aspect must be considered by law enforcement officials at the point of arrest. Some of these rights afforded to "everyone" or "every person" are the right to human dignity, life, freedom and security of the person, privacy, access to courts, and specific rights for arrested and detained and accused persons (including due process rights but also to challenge the lawfulness of detention and to be detained in conditions that are consistent with human dignity). ${ }^{48}$

In addition, arguments may arise about the extraterritorial application of the Constitution in the present context. The South African Constitutional Court has pronounced itself on the issue by stating that the South African Constitution is "territorially bound and has no application beyond our borders". 49 However, the judgment pronouncing thereon was concerned with persons already within the power, jurisdiction and territory of a foreign state, and not persons finding themselves within the power or under the control of South African law enforcement authorities. It would be unthinkable that a foreigner arrested by South African authorities just beyond the limits of the South African territorial sea on suspicion of being involved in illegal fishing, and who then appears before a South African court would not be able to claim due process in accordance with the South African Bill of Rights because anything beyond the limits of the territorial sea is technically outside the "territory" of the Republic. Notwithstanding extra-territorial law enforcement, the Constitution remains the supreme law of the Republic, ${ }^{50}$ and conduct inconsistent with it will be invalid, while the obligations imposed by it must be fulfilled in the process of South African authorities bringing a foreign suspect to a South African court. In any event, the state is obliged to respect, protect, promote and fulfil the rights in the Bill of Rights, ${ }^{51}$ and teach and require the members of the security services to act in accordance with the Constitution and the law. ${ }^{52}$ Finally, it would not make sense to apply South African fisheries legislation beyond South African territory (i.e. in the EEZ), and then allow those same officials to disregard the

${ }^{46}$ E.g. s 3, 19, 20 and 22.

${ }^{47}$ E.g. $\mathrm{s} 9$ to 18 but in particular s 34 and 35 .

${ }^{48}$ S 10 (Human Dignity), 11 (Life), 12 (Freedom and Security of the Person), 14 (Privacy), 34 (Access to Courts) and 35 (Arrested, Detained and Accused Persons).

${ }^{49}$ Kaunda v The President or the Republic of South Africa 2005 (4) SA 235 CC at 35.

${ }^{50} \mathrm{~S} 2$.

${ }^{51} \mathrm{~S} 7$.

${ }^{52} \mathrm{~S}$ 199(5). 
Constitution when enforcing such legislation.

With reference to the rights of arrested and detained persons, the Constitution dictates that an arrested person must be brought before a court as soon as reasonably possible, but not later than 48 hours after the arrest (or the end of the first court day after the expiry of the 48 hours, if the 48 hours expire outside ordinary court hours or on a day which is not an ordinary court day). ${ }^{53}$ The Constitution also provides for the limitation of rights only in terms of law of general application to the extent that the limitation is reasonable and justifiable in an open and democratic society based on human dignity, equality and freedom, taking into account all relevant factors. ${ }^{54}$ The Constitution provides that the Bill of Rights is to be interpreted in the light of international law, and also that "[c]ustomary international law is law in the Republic unless it is inconsistent with the Constitution or an Act of Parliament". ${ }^{55}$ The Constitution also stipulates that the SANDF must act in accordance with international law. ${ }^{56}$ The implication is that international human rights obligations of South Africa as well as the international law regime regarding the use of force in maritime law enforcement operations are applicable to the SANDF in the context. Section 50 of the Criminal Procedure Act (CPA) prescribes the procedure after arrest and makes provision for instances where it is not possible to bring the person to the relevant court within the constitutionally mandated 48-hour period. ${ }^{57}$ If the period of 48 hours expires at a time when the arrested person is outside the area of jurisdiction of the lower court to which he or she is being brought for the purposes of further detention, and he or she is at such time in transit from a place of detention to such court, the period shall be deemed to expire at the end of the court day following the day on which such arrested person is brought within the area of jurisdiction of the court. ${ }^{58}$ The requirement in South African law that an arrested person be brought before a court within 48 hours has an exception that is applicable to the matter in question, and which allows South Africa to detain suspected maritime criminals for longer periods. The minimum guarantees to be afforded to such suspects are, by law, equal to those afforded to any accused in South African courts, and are generally equal to or more than that demanded by international human rights instruments.

It is anticipated that a challenge to detention for longer than the prescribed minimum period will be dealt with in the same manner as it has been dealt with by

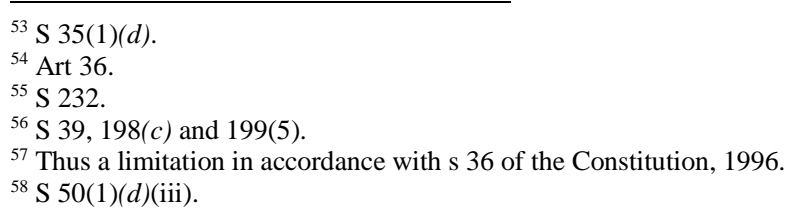


the ECtHR, meaning that the 48-hour requirement in section 35 of the Constitution could be found to have been limited in accordance with section 36 of the Constitution by section 50 of the CPA, 1977. The South Africa court that may be required to consider the matter must consider international law, and may rely on the jurisprudence from the ECtHR in any event for interpretative purposes in accordance with sections 39(1) and 232 of the Constitution.

The conditions and place of detention on a naval vessel will be influenced by the class and size of the vessel, and the overriding provisions of the safety and security of the vessel, crew, passengers and the detained persons. Simply put, smaller naval vessels are not the most spacious or accommodating in terms of the options for detention, and whatever would be practical in the circumstances will have to suffice. Larger vessels have options with reference to lockable cabins or other spaces, but the 'luxury' of a dedicated cell or holding facility may elude the detained person. Except for adequate exercise facilities, various alternatives are available that could be employed by the crew to detain in compliance with human rights requirements, which demand that the conditions of detention must be consistent with human dignity and the provision, at state expense, of adequate accommodation, nutrition, reading material and medical treatment. ${ }^{59}$

\section{Possible considerations for military planners and commanders}

With the SANDF being empowered to enforce South African law at sea, the military commanders have several issues to consider when receiving a tasking to deploy for this purpose. Military considerations are generally divided into different levels, and there are as important considerations at national strategic and military strategic levels as there are at operational and tactical levels. This article is not concerned with the national or military strategic consequences of maritime law enforcement operations, and will assume that the deployment of the SANDF in maritime law enforcement operations has been properly authorised at national executive level in accordance with the requirements indicated above.

On a conceptual level, international humanitarian law is not applicable to maritime law enforcement operations. Only domestic and international human rights law are applicable in the circumstances. ${ }^{60}$ Thus, it requires a military commander to remove the traditional soldiering 'helmet' and to replace it with the unconventional 'policing' cap where the precedence of the mission is replaced by the precedence of fundamental rights and freedoms. This is possibly the most difficult consideration

\footnotetext{
${ }^{59} \mathrm{~S} 35(2)(e)$ of the Constitution, 1996.

${ }^{60}$ Smit op cit $188-90$.
} 
for the military commander, as it requires a re-calibration of the postures and preparation of an entire military crew or contingent from soldier to law-enforcer. This is an over-arching consideration that can only be fully complied with by sufficient and well-rehearsed prior training that must take place long before the actual boots hit the 'deck'.

Then, once a tasking is received, it can be expected to come from the president, or the Minister of Defence and Military Veterans in the event of reliance upon sections 18(1)(c) and 18(1)(d) of the Defence Act, 2002, or from the Minister of Defence and Military Veterans if the deployment is authorised in terms of section 19(1) of the Defence Act, 2002, read with section 201(2)(a) of the Constitution. ${ }^{61}$ Section 18(1)(c) would relate to the supporting of a department of state in the maritime domain. Section $18(1)(d)$ would relate to the effecting of national border control at sea, and section 19(1) would relate to employment in cooperation with the SAPS in the maritime domain. ${ }^{62}$ In each of these three instances, it is important to understand what the specific powers are that are conferred on members of the SANDF so deployed when the SANDF is employed for those purposes, as the position is not the same as when the SANDF would be employed specifically for law enforcement at sea in accordance with Chapter 4 of the Defence Act, 2002.

Section 19(3) of the Defence Act, 2002, determines that service in cooperation with the SAPS will be limited to a specified geographic area, and is subject to the temporal control of the president. Such service must also be performed in accordance with a code of conduct and operational procedures approved by the Minister of Defence and Military Veterans, and such guidelines regarding cooperation between the SANDF and the SAPS as the chief of the SANDF and the National Commissioner of the SAPS may determine. The section 19(3) requirements are not relevant in the instances of sections $18(1)(c)$ and $18(1)(d)$ employments, and are also not relevant in instances of employment under Chapter 4 of the Defence Act, 2002. The specific powers conferred on members of the SANDF while employed for service under section $18(1)$ and 19(1) are equated to the powers of a member of the

${ }^{61} \mathrm{~S}$ 18(7)(a) of the Defence Act, 2002, also provides for an exception wherein the Secretary for Defence may authorise the employment of the SANDF if the authorisation by the Minister of Defence and Military Veterans cannot be obtained in time to avert imminent danger to life, health or property, but that can only be done in terms of a standing delegation by the Minister of Defence and Military Veterans, and with the concurrence of the Chief of the SANDF.

${ }^{62}$ Maritime law enforcement operations appear to have been authorised under the guise of national border control in the past, as can be seen in the short report by Skommere, $\mathrm{P}$ 'Operation CORONA' (2015) XXXIV (6) Navy News at 23, wherein it was reported that the SA Navy deployed the Maritime Reaction Squadron under Operation CORONA (the SANDF national border control operation) to, amongst others, protect the marine living resources against illegal harvesting. 
SAPS by virtue of section 20(1) of the Defence Act, 2002, where mention is made of the powers conferred on members of the SAPS by specified portions of legislation, such as:

- $\quad$ the South African Police Act, 1995 (Act No. 68 of 1995);

- $\quad$ the Regulation of Gatherings Act, 1993 (Act No. 205 of 1993);

- $\quad$ the Criminal Procedure Act, 1977 (Act No. 51 of 1977);

- $\quad$ the Arms and Ammunition Act, 1969 (Act No. 75 of 1969); and

- $\quad$ the Road Traffic Act, 1989 (Act No. 29 of 1989).

However, such powers and duties may only be exercised or performed for the purposes of successful execution of employment, the prevention of crime, the maintenance of law and order, or the preservation of the internal security of the Republic of South Africa, and the powers specifically exclude the power to investigate crime. ${ }^{63}$ Military planners will have to assess the purposes of the operation carefully to ensure that such purposes are indeed authorised by law, and then to draw the appropriate powers from each of the laws mentioned in order to facilitate appropriate training to operators on the relevant provisions and related procedures.

Section 20(4) to 20(10) of the Defence Act, 2002, is explicit in its determinations regarding -

- the handing over of suspects and evidence;

- liability of members of the SANDF;

- $\quad$ benefits and indemnities applicable to members of the SANDF;

- conferring of the powers attached to a peace officer as defined in the Criminal Procedure Act, 1977;

- conferring of other powers ordinarily conferred on SAPS members holding specific ranks;

- the command-and-control arrangements between the SAPS and the SANDF;

- $\quad$ specific interrogation, seizure of weapons, arrest and detention, in relation to border control; and

- $\quad$ the retention of powers otherwise conferred on members of the SANDF.

Of particular importance to the military commander, and especially to the planners and executors of military operations, is that members of the SANDF so employed must receive appropriate training prior to such employment, and must be equipped accordingly. ${ }^{64}$ This implies that the military personnel who will be expected to take part in the operation be properly trained in the handling of suspects

${ }^{63} \mathrm{~S} 20(2)$ and (3).

${ }^{64} \mathrm{~S} 20(11)$. 
and evidence, seizure and arrest, and be issued with appropriate equipment to mark, safeguard and process evidence.

In contrast to the somewhat complex procedure to employ the SANDF in terms of sections 18 and 19 of the Defence Act, 2002, the employment of the SANDF to conduct law enforcement at sea specifically is an abbreviated procedure that requires only a request by a competent minister, and a decision by the chief of the SANDF with the concurrence of the Minister of Defence and Military Veterans. ${ }^{65}$ It does not, by virtue of any legal requirement, involve the president, and is an indication of the legislature being aware of the need to have a time-sensitive procedure in place to employ the SANDF quickly in instances of maritime crime. The chief of the SANDF may then authorise the use of any military aircraft, warship or member of the SANDF for the purpose of enforcing any provision of South African law at sea. ${ }^{66}$ Of paramount interest to the military commander is that the Defence Act, 2002, specifies the powers of members of the SANDF in this instance separately from the powers previously specified in relation to employments as contemplated in sections 18 and 19. Military planners and commanders will have to keep in mind that the 'menu' of powers under an employment in terms of Chapter 4 of the Defence Act, 2002, differs from the other possible employment authorisations, and it is important that powers conferred in other instances not be inadvertently relied on in situations wherein those powers are not conferred.

Section 23 deals with interests to be considered if (law) enforcement actions are being taken against a foreign ship. Section 24 incorporates the international law crime of maritime piracy into South African law, defines the crime, determines the penalties, and indicates which courts will have jurisdiction. Amongst other aspects, section 25 deals with the seizure of pirate ships or aircraft, and provides that an officer of the SANDF may seize a ship or aircraft and the property on board, and arrest any person on board, in accordance with the relevant provisions of UNCLOS. It also provides that any officer of the SANDF who exercises any power referred to in section 25 inside or outside the Republic of South Africa, must be regarded as being a peace officer as defined in section 1 of the CPA, 1977. Section 26 deals with the right of visit on the high seas by warships of the SANDF, while section 27 provides for hot pursuit of ships. Section 28 provides that SANDF warships and SANDF (military) aircraft are to render assistance at sea, and section 29 provides for the cooperation with foreign states in law enforcement at sea. Many specific law enforcement actions are mentioned in this portion of the Defence Act, 2002, and the standard operating procedures and doctrine will have to be customised to incorporate

\footnotetext{
${ }^{65}$ Chapter 4 of the Defence Act, 2002.

${ }^{66} \mathrm{~S} 22(1)$.
} 
these specific actions in a legally compliant manner.

Sections 22(2) and 22(3) are drafted in such a manner as to comply with the requirements of international law regarding the exercise of jurisdiction. These sections limit the powers conferred by the Defence Act, 2002, by explicitly determining that the powers must be exercised in accordance with the applicable articles of the UNCLOS, and also confirms the international law position that South African law enforcement officials will have powers to enforce South African law outside South African territorial waters, and even on the high seas or in the maritime zones of any other coastal state other than the territorial waters of the foreign state, as long as it is permitted by international law. In conformance with international law, the Defence Act, 2002, also permits the exercise of jurisdiction on foreign-flagged vessels or against those on board such vessels. These provisions force a military commander and planner to constantly be fully aware of the relative positions of own forces and suspects, and to confirm the nationality of suspects. ${ }^{67}$

When law enforcement powers at sea are delineated, the Defence Act, 2002, is careful to confer the powers on commissioned officers only, and when acting in this capacity, those officers are regarded as being peace officers as defined in the CPA, 1977. The officers concerned are also obliged to exercise such power in the same manner as a peace officer exercising such powers within the Republic of South Africa, but may also exercise all other powers referred to in Chapter 4. It then takes the matter much further by conferring "all or any" of the powers conferred on any enforcement authority in terms of the legislation being enforced by the officer, on such officer. This is a wide-ranging provision that effectively converts SANDF officers into lawfully empowered customs, immigration, fisheries inspection, marine safety enforcement, or pollution control officers, if the legislation that is being enforced by the SANDF officers provides for law enforcement powers in the context. The subordinate's powers to enforce South African law at sea is then linked to the commissioned officer's powers to do so, and must be exercised under control and direction of the commissioned officers concerned.

The effects of these provisions are that the SANDF officer may be required to enforce laws which would ordinarily require the enforcing official to be trained in at an expert level, and the SANDF officer could hardly be expected to have full knowledge of such laws. This situation could obviously hold great risk for the SANDF officer and the state if the law enforcement does not comply with the legal technicalities required by the laws being enforced. This may lead to evidence being

${ }^{67}$ As an extreme example, see the report regarding an incident in 2016 when an Argentinian vessel sank a Chinese vessel suspected of fishing illegally in the Argentinian EEZ at https://thediplomat.com/2016/03/argentina-coast-guard-sinks-chinese-fishing-boat/. 
obtained unlawfully, and to arrests and detentions being declared unlawful, illegal or even injurious to a suspect. The way powers are linked to commissioned officers also implies that actions under the control of any rank lower than a commissioned officer rank is at risk of being regarded as ultra vires. The planner and commander must ensure that even the lowest tactical level actions are exercised under the command and control of a commissioned officer, and may even want to consider that a commissioned officer be present at the lowest level of law enforcement activity in order to ensure that the law enforcement actions are clothed with legality, or that subordinates are at least aware that decisions will preferably have to be referred to commissioned officers for the purposes of law enforcement, even though lower ranks could otherwise have been empowered to make tactical decisions.

Regarding the use of force, and the drafting of rules of conduct and engagement for law enforcement at sea, it must be understood that rules of conduct and engagement drafted for conventional law of armed conflict is not suitable for maritime law enforcement operations and, as is the case with peace support operations, rules of conduct and engagement for maritime law enforcement operations must be carefully chosen and drafted to take international and domestic law into account. The drafting of such rules of conduct and engagement is complicated by the fact that every deployment that is based on a different law or employment provision may require changes to the rules of conduct and engagement because the powers conferred may differ. Planners and commanders will have to make full use of their assigned legal advisers to make sure that full compliance is ensured. The remarks made in relation to the use of force above remain very relevant in the present context too.

What should be evident from the discussion above is that the determination of the specific legal basis for the SANDF's employment is not only important for the authorisation of the actions on the part of the SANDF, but also determines the powers of members, keeping in mind that the powers when employed specifically for law enforcement at sea are different from when employed in support of the SAPS. In this regard, the rules of statutory interpretation require that a specific provision that deals with a particular matter be preferred above a general provision that may also regulate the same matter. ${ }^{6}$ Consequently, even though it is possible that the SANDF may enforce South African law at sea incidentally due to an employment to effect national border control, support the SAPS or defend the territorial integrity and sovereignty of the Republic of South Africa, the specific provisions relating to employment for law enforcement at sea must be activated to confer powers on the SANDF and

${ }^{68}$ Expressio unius est exclusio alterius and generalia specialibus non derogant. 
preferred over other general employment authorisations.

The military commander will also be wise to take note that in instances of violation of the law of a foreign state, the law provides for any SANDF officer serving on a warship or military aircraft to seize a vessel, arrest persons aboard such vessels, seize property aboard such vessels, conduct hot pursuit in relation to such a vessel, escort the vessel to a foreign port and surrender the vessel, persons and property to the authorities of a foreign state. ${ }^{69}$ However, such actions are only allowed if there exists a reciprocal agreement on co-operation in law enforcement at sea with the foreign state concerned, the measures are taken in accordance with such agreement, and the foreign state is competent to take such actions under international law. In addition, it appears that hot pursuit is only provided for in the context of law enforcement at sea, and is not provided for in operations supporting the SAPS or other government departments.

\section{Conclusion}

South Africa has a major interest to protect in the maritime domain, and financial constraints on the SANDF do not make it easy to provide the support required to safeguard South African interests. By being a regional role player with capabilities that far exceed those of most other states in the region, it is not only of national interest, but also of regional and international interest that this capability be maintained, and even expanded. It also requires extraordinary insight into the effect that a shift from conventional military operations to law enforcement operations brings to the military operator, and this role demands that the unique tasks of law enforcement at sea be incorporated into training and doctrine at a very formal and institutional level for compliance to be ensured, and the interest to be safeguarded within the limits of the law.

What this article has not done, was to analyse and explain the lowest tactical level of legal considerations, which are the method of arrest, seizure, detention and other related actions. The experience and training that departments, other than the Department of Defence, engaged in law enforcement receive could be harnessed in combined training and exercises to empower the SANDF and its members to become sufficiently acquainted with the detailed requirements of the execution of law enforcement actions.

This article should also not create the impression that the SANDF has been unaware of the issues touched on herein, as there are many highly capable and

${ }^{69}$ S 29 of the Defence Act, 2002. 
professional officers who have been, and are, already working on refining and further improving the capabilities of the SANDF. However, as any soldier knows, it is only through continuous assessment of performance, continuous training and re-training, and the opportunity to execute drills in operations that the required level of perfection can be attained. A quote ascribed to Sir William Francis Butler rings true: "The nation that will insist upon drawing a broad line of demarcation between the fighting man and the thinking man is liable to find its fighting done by fools and its thinking by cowards." ${ }^{70}$ The SANDF certainly contains its share of brave and wise soldiers, and it is hoped that this article will assist our warriors to continue fighting and thinking at the same time.

${ }^{70}$ Butler, WF Charles George Gordon (Macmillan \& Co. 1889) at 85. 